\title{
Evidence of the Development of Pedagogical Content Knowledge Related to Chemical Bonding during a Course for Preservice Chemistry Teachers
}

RoKo Vladušić ${ }^{\star 1}$, ROBERT BuCAT ${ }^{2}$ AND Mia OžIĆ ${ }^{3}$

$\approx$ The impression that many preservice chemistry teachers demonstrate issues in the application of their pedagogical content knowledge in teaching practice, especially in the area of fundamental chemistry topics, served as motivation for changes to the Chemistry Education 2 course curriculum. In order to stimulate pedagogical content knowledge, the course has been changed in the following areas: intending learning outcomes, the language of chemistry instruction, awareness of "Johnstone's triangle" of operations, and common alternative conceptions.

To obtain evidence of preservice teachers' in-practice pedagogical content knowledge about chemical bonding, especially pedagogical content knowledge related to the revised areas of the Chemistry Education 2 course, we designed and conducted a case study based on detailed monitoring of one preservice teacher's pre-teaching, teaching and teaching evaluation activities. The findings demonstrate evidence of growth of the preservice teacher's pedagogical content knowledge of chemical bonding, with particular characteristics indicating that the source of this growth is almost certainly the revised Chemistry Education 2 curriculum.

Keywords: chemical bonding, Chemistry Education course, pedagogical content knowledge, preservice chemistry teachers

$1 \quad{ }^{\star}$ Corresponding Author. Faculty of Science, University of Split, Croatia; vladusic@pmfst.hr.

2 School of Molecular Sciences, University of Western Australia, Austraila.

3 Faculty of Science, University of Split, Croatia. 


\section{Razvoj pedagoškovsebinskega znanja o kemijski vezi med izobraževanjem učiteljev kemije}

Roko Vladušić, Robert Bucat in Mia Ožić

$\approx$ Mnenje, da se v šolski praksi številni študentje študijskih programov izobraževanja učiteljev kemije spoprijemajo s težavami uporabe njihovega pedagoškega vsebinskega znanja, še zlasti na področju osnovnih kemijskih pojmov, je služilo kot motivacija za spremembe učnega načrta predmeta kemijsko izobraževanje 2. $\mathrm{Z}$ namenom spodbujanja razvoja pedagoškovsebinskega znanja je bil predmet spremenjen na naslednjih področjih: pričakovani učni dosežki, jezik pouka kemije, zavedanje pomena "Johnstonovega trikotnika in pogosta napačna razumevanja. $\mathrm{Da}$ bi raziskali pedagoškovsebinsko znanje študentov študijskih programov izobraževanja učiteljev v praksi na temo kemijskih vezi, še zlasti pedagoškovsebinsko znanje, povezano s prenovljenimi področji učnega načrta predmeta kemijsko izobraževanje 2, je bila zasnovana in izvedena študija primera, ki je temeljila na natančnem opazovanju študenta in njegovih učnih priprav, poučevanja in evalvacije poučevanja. Izsledki kažejo na povečanje študentovega pedagoškega vsebinskega znanja, povezanega $\mathrm{z}$ učno temo kemijska vez, saj posebne značilnosti kažejo, da je vir te rasti skoraj gotovo prenovljeni učni načrt predmeta kemijsko izobraževanje 2 .

Ključne besede: kemijska vez, predmet Kemijsko izobraževanje, pedagoško vsebinsko znanje, študenti študijskih programov izobraževanje učiteljev kemije 


\section{Introduction}

\section{Current Research in Chemistry Education in Croatia}

In Croatia, research studies in chemical education have mainly been conducted by postgraduate students enrolled in the doctoral study programme Research in Education in the Field of Natural and Technical Sciences at the University of Split, as well as their mentors and colleagues.

Several authors have presented their findings through press releases, at scientific conferences, and as articles in national journals, while a few papers have had wider distribution in journals that can be found in international science databases.

Two of the international papers (Vladušić, Bucat, \& Ožić, 2016a, 2016b) are related to the concept of pedagogical content knowledge (PCK) in the Croatian chemistry education context. PCK has come to be recognised as perhaps the most important part of the armoury of successful teachers.

The motivation for the research reported here was the belief that programmes for education of preservice teachers should include raising awareness of the importance of PCK, that is, knowledge beyond content knowledge and content-independent pedagogical knowledge.

University professors have perceived that, in the past, even when preservice teachers showed evidence of good chemistry knowledge and good pedagogical knowledge, many demonstrated deficiencies in PCK in their teaching practice, even with regard to fundamental chemistry topics. Traditionally, recognition of the importance of PCK, and accumulation of a store of PCK, has been derived only from experience as teachers.

At the University of Split, a preservice teacher education programme has been designed to develop the PCK of the enrolees, particularly with respect to the topic of chemical bonding. We have chosen to present insights into the efficacy of this course insofar as it has influenced the PCK of one participant. The research undertaken is in the form of a case study: a story of the experiences and thinking processes of one preservice chemistry teacher.

\section{Pedagogical Content Knowledge}

Shulman (1986) proposed distinguishing three categories of teacher knowledge: (a) knowledge of content, (b) pedagogical content knowledge (PCK), and (c) knowledge of the curriculum.

Among those categories, PCK is of particular interest (Shulman, 1987). 
PCK is a specific form of knowledge based on the translation of content knowledge (e.g., chemistry) to content knowledge for teaching. More specifically, PCK is knowledge of the effective teaching of particular topics, concepts, issues and ideas.

Since Shulman introduced PCK, the concept has attracted a great deal of attention from both teachers and researchers. Its development has therefore continued intensively. Geddis, Onslow, Beynon and Oesch (1993) defined PCK as transforming knowledge of subject content into forms adapted for student teaching. Bromme (1997) reflects on PCK as the knowledge and skills necessary for the conversion of content items in the content adapted to lecture students, emphasising that the way of teaching is independent of the content that we present.

At the turn of the century, in the 1990s and early 2000s, new directions for the conceptualisation of PCK emerged. Some scholars have emphasised the role of PCK in action (Cochran, De Ruiter, \& King, 1993; Van Driel, Verloop, \& de Vos 1998, 2002), while others present PCK as a set of knowledge from multiple fields and highlight its role in monitoring and evaluating teaching itself (Magnusson, Krajcik, \& Borko, 1999).

Major changes have come about in the last decade following the first PCK Summit held in 2012. Due to inconsistent models and different research methods, the PCK Summit identified weaknesses that have theoretically and practically limited the usefulness of PCK in this field (Carlson, Stokes, Helms, Gess-Newsome, \& Gardner, 2015). The result of the multi-day discussion was a model of teacher professional knowledge (Gess-Newsome, 2015).

Over the years, various models have evolved, which occasionally diverge from the Shulman's original idea. We still cannot say that there is a consensus regarding the PCK model. One of the most accepted instances is the PCK model devised by Magnusson et al. (1999), which is constructed with five discrete components: 1) orientation towards science teaching, 2) knowledge and beliefs about the science curriculum, 3) knowledge of students' understanding of science, 4) knowledge of assessment in science, and 5) knowledge of instructional strategies. Due to its wide diffusion, we will follow Magnusson's PCK model in this paper.

\section{The Research Context: The Design of a Preservice Teacher Education Programme}

At the Faculty of Science, University of Split, preservice chemistry teachers enrol in a programme entitled Diplomski sveučilišni studij Biologija i Kemija - nastavnički smjer (approximately, University Diploma Study in Biology and Chemistry - Teaching Stream). Within this programme, those preparing to be 
school chemistry teachers undertake five courses, listed here in the order in which they are presented over three semesters: (i) Metodika nastave kemije 1 (Chemistry Education 1), (ii) Praktikum iz metodike nastave kemije 1 (Laboratory in Chemistry Education 1), (iii) Metodika nastave kemije 2 (Chemistry Education 2), (iv) Praktikum iz metodike nastave kemije 2 (Laboratory in Chemistry Education 2), and (v) Metodička praksa (Teaching Practice).

From our teaching experience and awareness of the chemical education literature, we recognised four specific aspects of chemistry-based PCK in which the students seemed to be deficient: a) intended learning outcomes, b) the importance of the "chemical triplet" (or "Johnston's triangle"; Johnstone, 1982), c) the hazards associated with the commonly used language of chemistry instruction (Markic \& Childs, 2016; Vladušić et al., 2016b), and d) awareness of alternative conceptions commonly held by school students, that is, beliefs and explanations that are not consistent with accepted science (Barker \& Millar, 2000; Boo, 1998; Coll \& Treagust, 2003; Taber, 2002; Vladušić et al., 2016a).

This motivated us to redesign the curriculum of the Chemistry Education 2 course in order to raise preservice teachers' awareness of issues (a) to (d) above. We also decided to conduct research to look for evidence that the revised course had influenced preservice teachers' PCK in practice.

Due to the abstract nature and fundamental importance of chemical bonding, and in view of previous research highlighting the challenges related to teaching this topic (Vladušić et al., 2016a), we decided to focus this intervention on preservice teachers' PCK of chemical bonding models.

\section{Design of the Revised Chemistry Education 2 Course}

The curriculum of the Chemistry Education 2 course was changed so that there was less emphasis on content with respect to the psychology of learning, sources of knowledge and presentation instruments, types of "teaching lessons", and evaluation issues. Instead, the course now involves more extensive and focused considerations of the four aspects referred to above, as described below in more detail:

\section{a) Intended learning outcomes}

Until a few years ago, the Croatian education system was based on teaching tasks, rather than on intended learning outcomes. Due to the fact that the change of paradigm from tasks to outcomes by teachers was more difficult than expected, this topic was included in the revised course. 
Intended learning outcomes are firstly taught theoretically, with an emphasis on their importance and on algorithms of writing, focusing on the different levels and types of knowledge and abilities as well as their evaluation. Preservice teachers are then involved in writing and evaluating intended learning outcomes through two workshops.

\section{b) The language of chemistry instruction}

This aspect was initially presented as a review of evidence from the literature regarding the importance of the careful use of chemistry language. In the revised curriculum, we introduced an original teaching and research method called OZO (Vladušić, 2017) for enhancing preservice teachers' awareness of the complexity of the language of chemical instruction and specific issues related to it, as well as for diagnosis of PCK changes. The method is based upon the use of two questionnaires: one designed to indicate students' expectations regarding the complexity of particular terms, and the other designed to evaluate students' understandings of those terms.

Special attention is also devoted to the meanings of scientific and nonscientific words, words with more than one meaning, and symbols used in chemistry instruction (Vladušić \& Ožić, 2016), followed by discussion about the complexity of their meanings and preservice teachers' expectations of students' understandings.

\section{c) Awareness of the "chemical triplet", or Johnstone's triangle}

The "chemical triplet", first suggested by Johnstone (1982), refers to chemists' operations at the levels of (i) macroscopic, observed phenomena, (ii) the submicroscopic modelled world of explanation, and (iii) symbolic language. Although the chemical triplet was part of the old curriculum, many preservice teachers demonstrated weaknesses in its application in teaching practice. In the revised curriculum, after theoretical consideration of the chemical triplet but before teaching praxis, preservice teachers were asked to design teaching scenarios focusing on the chemical triplet, and to explain the connectivity (and distinction) between the levels of the triplet.

\section{d) Common alternative conceptions}

During Chemistry Education courses, it was noticed that preservice teachers have some alternative conceptions. This has been demonstrated with 
research focused on preservice teachers' understandings of covalent bonding models (Vladušić, 2017) and the ionic bonding model (Vladušić et al., 2016a).

Trying to reconstruct the understandings of preservice teachers, we created a specific teaching (and research) strategy based on cognitive conflict, called Open Interview (Vladušić, 2017). The strategy is based on a semi-structured conversation on a predetermined topic between two preservice teachers, observed by others. The conversation is led by questions, claims and graphics. At a specific moment, the observers are invited to participate in the discussion.

\section{The Research: Overview and Research Questions}

We designed and conducted a qualitative research study to obtain evidence of preservice teachers' in-practice PCK with respect to chemical bonding, with proofs of potential development of their PCK gained by learning and teaching.

The research is based on monitoring preservice teachers' pre-teaching, teaching and teaching evaluation activities, and is guided by research questions 1 (RQ1) and 2 (RQ2):

1. What evidence can be detected of the development of preservice chemistry teachers' PCK about chemical bonding that can be attributed to participation in the component of the Chemical Education 2 course that was designed to stimulate PCK?

2. What other evidence can be detected of the preservice chemistry teachers' PCK about chemical bonding that cannot be directly attributed to participation in the component of the course redesigned to stimulate PCK (and must therefore be an outcome of the preceding components of the Chemical Education programme)?

\section{Method}

\section{A Case Study Approach}

Sixteen preservice chemistry teachers enrolled in their last year of the Biology and Chemistry graduate study programme at the Faculty of Science, University of Split, were involved in the research. Each of them performed one teaching lesson in a first-grade class (15-year-old students) of a grammar school. Since we wanted to gain a deeper insight into a personal story, we decided to select one of the preservice teachers as a case study.

The selected student's understandings and thinking processes were monitored in considerable detail during her teaching (preparation, praxis and 
testing) in the topic Introduction to Chemical Bonding. For ethical reasons, we use a false name, Antonia.

Yin (2014) recommends that case study is the preferred method when (i) the main research questions are "how" or "why" questions, (ii) the researcher has little or no control over behavioural events, and (iii) the focus of study is a contemporary phenomenon (occurring in a real-world context). All of these conditions apply in the present study. Although one might argue that the researchers have influenced behaviour through the design of the course, in fact the new course is the real context and the researchers have no control over how the subject reacts to instances within that context: they can only investigate "How?" or "Why?".

Within the constraints of the limited resources, it was decided that the most valuable outcome could be derived from deep-level, forensic monitoring of just one student, rather than more superficially monitoring more students, the extreme case of which is a survey. In this way, the researchers expected that evidence of interaction between the nature of the course and the teacher's PCK growth would be insightful, even if it is not representative.

The selection of Antonia as the subject of study was entirely a matter of opportunity and circumstance: she had often demonstrated good analytical awareness of her thinking and understanding, and was relatively uninhibited in discussing them. Furthermore, she volunteered to participate.

Coincidentally, based on her previous performance in chemistry, Antonia could be described as a "middle-of-the-road" student. This is not to imply that the researchers regarded her as a statistical average of the whole class, or in some way representative of the entire class.

No attempts were made to compare the PCK development of Antonia with other students, either within the class or external to the class.

The case study was not concerned with comparability between students or groups of students, and no claims are made about the degree of commonality between the critical features that were influential in Antonia's PCK development, and those that might have influenced the development of others.

Rather, it was an exploratory study searching for evidence that the newly designed curriculum had indeed influenced Antonia's PCK, identifying circumstances under which such development occurred, and trying to understand the nature of Antonia's interactions with teaching situations that gave rise to increased PCK.

The case study may well serve as a starting point for further studies that compare how different classes of people (classifications based on gender, previous grades or personality types, for example) interact with particular situations designed to engender PCK. 


\section{Instruments}

During the research, preservice teachers were involved in the following activities: a) analysis of the sequence of teaching units in the Chemical Bonding chapters of the textbook, and reflection upon how the sequence might be improved, b) completing a lesson preparation sheet, c) performing a teaching lesson, d) reflection and self-evaluation of teaching, and e) evaluation of colleagues' teaching.

More details about the instruments are provided below.

a) The preservice teachers' analysis of sequencing the Chemical Bonding chapters in the textbook, with reflections and decisions reported on blank paper, supported by arguments and justifications.

b) A lesson preparation sheet was designed in such a way that the preservice teachers needed to think about and express lesson goals, alternative conceptions published in the scientific literature, lesson-related terms that the preservice teacher expected the students would already know, new terms that should be introduced during the lesson, intended learning outcomes, questions for evaluation of the intended learning outcomes, possible limitations and obstacles, critical analysis of textbook content related to the lesson, big ideas, relevant examples of the distinction between the macroscopic and submicroscopic worlds, elaboration of sources of knowledge and key terms, the flow of teaching and learning activities, a plan of blackboard usage, and emotional prediction (about classroom atmosphere).

c) Teaching lesson performances were video recorded for analysis and evaluation.

d) A self-evaluation sheet was required to be completed within one day of the teaching performance. In addition, each preservice teacher was expected to give a final review of her/his performance and recommendations for possible improvement.

e) As well as the preservice teacher who was engaged in practice teaching, at least seven colleagues were present to keep field notes, which they were expected to use in an evaluation of the teaching performance.

The evaluation of teaching instrument (sheet) had two parts: the first was taken from the Handbook for Observation and Improvement of Teaching (Bezinović, Marušić, \& Ristić Dedić, 2012.) and had 31 general questions related to classroom performance, each with 5 answer choices, while the second part required an expression of personal impressions of the teaching quality, 
aspects that were highly rated as well as aspects that could be improved, and self-evaluation of the development of the evaluator's own PCK related to chemical bonding.

\section{Organisation of the Results}

The achievement of the preservice teacher is expressed as a story. The story is guided by data collected with research instruments in the following order: teaching unit sequencing, lesson preparation sheet, teaching performance, self-evaluation of teaching, and evaluation of teaching. PCK evidence related to the four revised areas of the Chemistry Education 2 curriculum was searched in all of the instruments' data. However, they are mainly presented and discussed in the teaching performance paragraphs, because we are very interested in correlating the revised curriculum of Chemistry Education 2 and the PCK of the preservice teacher demonstrated in teaching practice. PCK evidence is recorded and classified according to the domains of the PCK conceptualisation of Magnusson et al. (1999).

\section{Results and Discussion}

\section{The Story about Antonia's Thinking and Her Experience}

Antonia had demonstrated middle-of-the-road achievement in Chemistry Education courses. She was responsible and committed. At the beginning of the Chemistry Education 1 course, she demonstrated a traditional view of teaching, that is, she chose teaching scenarios ${ }^{4}$ mainly based on chalk, blackboard and the teacher's didactic verbal presentation.

\section{Sequencing of the teaching units}

The preservice teachers analysed the order of the teaching units in the two relevant chapters of the school textbook. In the chapter Chemical Bonds, the units were in the order "What is a Chemical Bond?", "The Covalent Bond", "The Arrangement of Atoms in Molecules", "Exceptions to the Octet Rule", "The Polarity of Molecules", "Intermolecular Forces", "The Ionic Bond" and "Metallic

4 At the beginning of preservice chemistry teachers' enrolment in the first Chemistry Education course - Chemistry Education 1 - candidates completed a questionnaire that consisted of tasks with different teaching scenarios. The results of the questionnaire served to indicate preservice teachers' starting points regarding chemistry teaching issues, and enabled the monitoring of their progress during and after completing all of the obligations related to Chemistry Education courses. 
Bonding". In the following chapter, Crystals, the units were "The Type of Chemical Bond and the Properties of Crystals", "Metallic Crystals", "Ionic Crystals", "Molecular Crystals" and "Atomic Crystals".

Antonia was reasonably satisfied with the order of the units. However, she proposed some relatively small changes, because she thought large-scale reordering could cause difficulties for students to manage the textbook content.

She decided that she would introduce exceptions to the octet rule before the unit on the arrangements of atoms in molecules, so that students will be able to understand how atoms in molecules with a trigonal bipyramid or octahedral shape are arranged.

Also, she stated that she would teach about atomic and molecular crystals after intermolecular forces, but before ionic bonding, so that students would be able to connect the covalent bond model and intermolecular forces with the macroscopic properties of atomic (covalent) and molecular crystals.

I would teach ionic crystals after ionic bonding, she wrote. In that way, students will connect macro and sub-micro worlds.

By reordering the teaching units, or segments of units, Antonia demonstrated knowledge of the science (chemistry) curriculum (Magnusson et al., 1999). Sibandas (2018) believes that the way teachers sequence chemistry lessons can be an indicator of their topic-specific professional knowledge according to the PCK model of Gess-Newsome (Gess-Newsome, 2015). This sensible reordering of teaching units is a partial response to $\mathrm{RQ}_{2}$.

In addition, and with regard to RQ1, Antonia demonstrated an awareness of the chemical triplet and an understanding of how the levels of representation should be distinguished in the area of chemical bonding. The way a teacher presents chemistry through the triplet relationship corresponds to their knowledge of representations (Adams, 2012), so this observation was judged as evidence of Antonia's PCK development in the domain of knowledge of science instructional strategies, and more specifically as evidence of her knowledge of topic-specific teaching methods and strategies, including representations (Magnusson et al., 1999).

\section{Lesson preparation sheet}

Antonia's allocated lesson was Introduction to Chemical Bonding. In general, she prepared a teaching plan for dynamic, interactive instruction, with a focus on important questions (big ideas). In the following discussion, we focus our attention on particular points related to RQ1.

Firstly, in the scientific literature, Antonia identified a few common alternative conceptions about chemical bonding related to her lesson. However, 
none of them were about the reasons why bonding occurs. Always, and especially in cases like this one, when the teacher knows nothing about her students' knowledge, awareness of common alternative conceptions recognised by others can be helpful. This kind of knowledge, as identified by Antonia, can be considered to belong to the PCK domain Knowledge of Science Learners (Magnusson et al., 1999). Although its importance is obvious, it is unreasonable to expect a preservice teacher, especially one with no in-service experience, to have this type of PCK at a higher level.

Antonia's textbook analysis was very good. She recognised instances of anthropomorphism, such as "...atoms feel..." and "Atoms of other chemical elements combine together to fulfil their valence shells". She considered the latter sentence to be misleading because "there is no explanation that atoms are combining to achieve the state with the lowest energy level". Although this could be considered as evidence of her PCK, it contradicts an intended learning outcome that she wrote: "Students will understand the octet rule as a model used for the explanation of chemical bond formation".

Antonia set three intended learning outcomes: a) Students will understand the nature and reasons for chemical bond formation; b) Students will understand the octet rule as a model used for the explanation of chemical bond formation, and c) Students will be able to represent atoms with Lewis symbols.

The intended learning outcomes were set on big ideas, but, as described above, one of them was based on an alternative conception, while two of Antonia's three intended learning outcomes were expressed with imprecise verbs (such as "will understand"). For example, a more precise expression of intended learning outcome a) is: Students will be able to explain the nature of chemical bonds and why bonding occurs.

Regarding the awareness of chemical language that can be recognised in Antonia's lesson preparation sheet, it was obvious that she gave it appropriate importance. All key terms were classified into two groups according to their novelty for students (new ones, or previously introduced ones). Some of them were imagined as focal points for discussions; for example, led by the instruction: "Please define the term 'interaction"'. Since it was effective, we consider this to be evidence of the development of Antonia's PCK domain Knowledge of Science Instructional Strategy (Magnusson et al., 1999).

Once again, Antonia showed PCK related to valid usage of the chemical triplet and demonstrated Knowledge of Science Instructional Strategy (Magnusson et al., 1999). More specifically, she planned to start the lesson focusing on water as a substance, before shifting the focus gradually to molecules of water, asking questions such as: "Why is our planet called a blue planet?", "What 
is water?", "What holds water molecules together?", "What atoms build water molecules?" and "What holds the atoms in water molecules together?".

\section{Teaching performance}

After completing the lesson preparation sheet, Antonia presented the lesson in school and the lesson was video recorded. Below is a short analysis of Antonia's accomplishment.

Antonia performed the teaching lesson based on a heuristic approach. She asked a lot of questions including the word why, but sometimes she was not patient enough and answered the questions herself. Although some students participated actively in the class, the lesson consisted almost entirely of studentteacher communication. Even discussions about her questions failed to provide opportunities for student-student interaction. The lesson was divided into three mini blocks, after each of which Antonia evaluated the students' knowledge.

It is not possible to draw conclusions about a teacher's orientation from one teaching lesson, but it seemed that Antonia had moved away from the traditional view of teaching presented at the beginning of the Chemistry Education 1 course to a preferable heuristic approach.

In the following paragraphs, we will shift our attention to evidence of Antonia's PCK demonstrated during her teaching, focusing on four modified areas of the revised Chemistry Education 2 course.

\section{Learning Outcomes}

We had the impression that Antonia's students had a reasonable level of understanding of the nature of chemical bonds and the reasons why chemical bonding occurs. However, many of them did not reach a point where they were able to write examples of atoms represented by Lewis symbols, and they could not fully explain Lewis symbol connectivity with an atom's electronic configuration using drawings of atomic orbitals. As might be expected of an inexperienced teacher, in the specific context regarding the teaching content and the limited lesson time, Antonia did not introduce the most appropriate examples of atoms for drawing Lewis symbols.

Specifically, Antonia's plan was to introduce Lewis symbols using a few simple examples just before the end of the class. In each example she decided to connect the Lewis symbol of an atom with the atom's electron configuration and its orbital distribution (she drew valence orbitals of an atom and placed electrons in orbitals), and to discuss the number of bonds an atom can establish in a molecule. She started with the example of an oxygen atom and followed with examples of carbon, beryllium and boron atoms, all three of which need to 
be supported with the simplest explanation of how atomic orbitals are imagined to form hybrid orbitals.

For example, when Antonia introduced a carbon atom Lewis symbol, and drew 2 s and $2 p$ orbitals and filled them with electrons, the students became confused as to why there is not a pair of dots and two single dots around the symbol for a carbon atom in its Lewis symbol when there is one full 2 s orbital (with two electrons) and two 2 p orbitals with a single electron in each of them. Antonia consequently mixed the orbitals, moving one electron from a 2 s orbital into an empty 2 p orbital, and explained that a carbon atom can use four single electrons for forming four bonds.

All of this was very challenging for the students, and they asked Antonia to explain it once more with a new example. Trying to help the students, she offered a new challenge - the example of a phosphorus atom's Lewis symbol - and made a mistake. One student called upon to draw a Lewis symbol of a phosphorus atom on the blackboard did it successfully, but Antonia asked him to draw valence orbitals of a phosphorus atom and move one 3 s electron to the first free d orbital. The student did what she asked and tried to verbally link the electronic configuration of a phosphorus atom with its Lewis symbol. Now, the problem was that five single dots in the Lewis symbol of the phosphorus atom (which arise from the hybrid orbitals diagram) for five electrons led to the conclusion that a phosphorus atom can form five bonds in a molecule, which is possible but in contradiction with the octet rule the students had been learning about 15 minutes earlier. Antonia was confused, as were the students. In this case, Antonia demonstrated neither Knowledge of Science Instructional Strategies, nor Knowledge of Topic-Specific Teaching Methods and Strategies, including representations as particular examples.

Regarding the second intended learning outcome, Antonia's misunderstanding of the octet rule, expressed as: "Students will understand the octet rule as a model used for the explanation of chemical bond formation", as demonstrated by a sentence in the lesson preparation sheet, was introduced to the students as a scientific fact. This finding is consistent with the conclusion of Joki and Aksela (2018) based on a study on the teaching of chemical bonding using the octet rule; namely, that explanations in science education need to be promoted both before teacher education and during professional development.

Returning to Antonia's lesson and her intended learning outcomes, it seems that only one of the three outcomes (Students will understand the nature and reasons for chemical bond formation) was achieved. These findings, related to RQ1, indicate that the changes to the Intended Learning Outcomes area in the Chemistry Education 2 curriculum had not been effective in Antonia's case. 


\section{Language of Chemistry Instruction}

There were more than a few instances to demonstrate that Antonia gave proper care to the language of chemistry instruction regarding the Chemical Bonding Introduction topic. She searched for the meanings of the word interaction in general and in the specific context. With the students, she discussed chemical bonds as interactions as well as intermolecular interactions, asking the following questions: "Why are interactions between atoms considered as chemical bonds, but interactions between molecules are not bonds?", "What type of change will occur if we break the interactions between atoms (chemical), and what type of change will occur if we break the interactions between molecules (physical)." In addition, she clearly stated that the octet rule is not a fact, but an artifice, principle or model, and that covalent, ionic and metallic bonds are nothing but models. For homework, the students had to write their own explanations of the following terms: atomic radii, ionisation energy, electron affinity and relative coefficient of electronegativity. This task demonstrates Antonia's awareness of the complexity and importance of concept words.

All of these meaningful questions, claims, activities and representations regarding the language of chemistry instruction are evidence related to RQ1 and the development of Antonia's Knowledge of Strategies for Specific Science Topics, which is part of Knowledge of Instructional Strategies (Magnusson et al., 1999). Moreover, Antonia’s language task could be considered as an indication of her Knowledge of Assessment in Science (Chemistry), more specifically, as Knowledge of Methods of Assessment (Magnusson et al., 1999), which refers to RQ2.

\section{Chemical Triplet}

During the introduction, Antonia successfully applied her plan to connect macroscopic and submicroscopic views of water, focusing on the properties of the substance and attractive forces between the particles, and giving emphasis by announcing the title of the lesson with the sentence: "Yes, those forces that keep atoms together we consider as chemical bonds." We have already written about chemical triplet findings as evidence relevant to RQ1 and Antonia's Knowledge of Instructional Strategies (Magnusson et al., 1999). The evidence of PCK described in this paragraph is an in-practice confirmation that, in Antonia's case, the Chemistry Education 2 curriculum redesign in the Chemical Triplet area was effective.

\section{Alternative Conceptions}

According to the lesson preparation sheet, Antonia was determined to recognise situations in which her students demonstrate or create alternative 
conceptions. We recognised this as evidence of her Knowledge of Students' Understanding of Science (Magnusson et al., 1999) and associate it with RQ1. However, besides the misconception regarding the octet rule as a model for the explanation of chemical bond formation, Antonia herself demonstrated an alternative conception, called conservation of force (Taber, 2003). This became obvious after she asked students why the atomic radii of different elements are smaller as we go to the right of any period of the Periodic Table of Elements. She agreed with a student answer that it is because the attractive power of the nucleus is increasing, too. Finally, using the sentence "We will introduce a new model that we are using to explain why chemical bonds are forming", Antonia gave wrong meanings to Lewis symbols.

These results show that, despite the focus on the school students' alternative conceptions and situations that could cause them, Antonia - as well as, we speculate, other preservice teachers - also holds alternative ideas and introduces them in practice. If preservice teachers were consistent with their own analysis of scientific literature about alternative conceptions (which is part of the lesson preparation sheet) during their preparation for each teaching unit, perhaps they would become aware of their own misconceptions and avoid them in future teaching situations.

\section{Other Evidence of PCK}

Antonia explained chemical bond formation with the help of graphical and numerical simulation of change in potential energy of a two-atom system if atoms were to approach each other and move away. The strong impression was that the students fully understood why bonding occurs, so it seems that the source of the knowledge (simulation) and the methods (demonstration and discussion) were selected and used successfully. Accordingly, we consider it as evidence of Antonia's PCK domain Knowledge of Science Instructional Strategies and, in this case, Knowledge of Strategies for a Specific Science Topic - Chemical Bonding. Since this evidence is not related to the areas of the Chemistry Education 2 course that were changed, but rather to the previous curriculum, this is associated with RQ2.

\section{Self-Evaluation of Teaching}

In general, Antonia was not satisfied with her accomplishment. More specifically, although she was very satisfied with the working atmosphere and some students' engagement, she thought that the intended learning outcomes were only partially achieved with regard to how the simulation of change in the potential energy of a two-atom system helped her to lead students to 
understanding why bonding occurs, and how discussion of the term interaction contributes to students' understandings of what a chemical bond is. She reported "I think that the octet rule is only partially adopted, and Lewis symbols are not adopted at all". One of the problems was that she overestimated the students' chemistry knowledge "because the grammar school is well known in the country as one of the best, if not the best" and when Antonia encountered the problem of students' poor understanding of Lewis symbols, she lacked ideas on how to bring the students to the outcome she had planned to achieve. She became aware that her range of Lewis symbol examples was not appropriate for introducing the concepts close to the end of the class, starting with symbol of the carbon atom: "That example was given in the textbook, and when I noticed that students were not following me, I introduced examples that are also the same kind of exceptions (she needed to mix atomic orbitals), and confused them even more. I should have ignored what is in the textbook and given only a few of the simplest examples in that moment", she concluded, demonstrating the growth of her PCK in the domains Knowledge of Science Learners, Knowledge about Science Curriculum, and Knowledge of Science Instructional Strategies (Magnusson et al., 1999). Such knowledge arises from in-practice topic-specific activities and could not be linked to Antonia's enrolment in previously conducted Chemistry Education courses.

Apart from the aforementioned details, Antonia recognised other aspects of her own teaching that could be improved: "I should insist on even more student interaction, especially of those students who weren't active at all. My questions need to be clearer and to provoke higher levels of knowledge. If I realise that the students are not following me, I should stop introducing new content and reflect on what they didn't understand". Finally, she concluded: "I'm not satisfied, I lack experience and creativity".

Antonia's self-evaluation shows numerous instances of how her PCK regarding teaching in general, and more specifically regarding teaching the Chemical Bonding Introduction for $1^{\text {st }}$ grade grammar school students, has grown. This is illustrated by her awareness of what was functioning in the classroom and what was not. Some evidence, such as language item discussion, is connected specifically with the revised Chemistry Education 2 curriculum, and thus RQ1.

A very important finding is that Antonia's PCK of chemical bonding models was developed through the process of her teaching. This is consistent with the findings of de Jong and van Driel (2004), who showed that an opportunity for learning from teaching appeared to be an effective way to evoke student teachers' awareness of specific teaching difficulties, as well as student-learning difficulties. 


\section{Evaluation of Teaching}

Seven preservice teachers evaluated Antonia's teaching. Their judgements, written in free style, were organised in four blocks: a) general impression of teaching, b) good aspects of the teaching process, c) areas of teaching that need improvement, and d) the development of their own PCK. Below are interpretations from their reports.

a) Although everybody had to study Antonia’s lesson preparation sheet before she executed her teaching in order to become familiar with her intended learning outcomes, all of her colleagues concluded that Antonia's teaching was successful. A few of them highlighted the end of the lesson with the introduction of Lewis symbols as the weakest part.

b) Extracts that refer to the good aspects of Antonia's teaching, which represent the largest share of her colleagues' thoughts, are: the example of water for introducing chemical bonding (because it enables linkage of tangible and abstract), the simulation of change in potential energy, lesson structure, clearly presented lesson content and explanation of language items related to the lesson, and communication with students.

c) We also identified a few of Antonia's colleagues' opinions regarding her teaching that suggest possible improvement:

Benita: When introducing Lewis symbols, Antonia didn't explain why, in cases of atoms of some elements, electrons should be transferred from one orbital to another, such as in the case of beryllium, but in some other cases should not, and it was a direct question of a student! That must be answered!

Marta: Lewis symbols should be explained much more simply. The term hybridisation should not be mentioned at all.

Ante: I was surprised that she was connecting Lewis symbols with orbital and going into it so deeply.

Neda: She should activate more students.

d) The preservice teachers were asked the question: "Has your knowledge about teaching of chemical bonding increased during this lesson?". Interestingly, everybody answered no. Two of them stated that it helped them to recall some chemistry concepts, such as Hund's rule.

The preservice teachers' evaluations indicate their lack of competence in the evaluation of teaching: nobody referred to the intended learning outcomes and whether they were achieved; they thought that their own impression was sufficient for judgement. However, they did recognise good aspects of teaching, some of which can be related directly to the redesigned areas of Chemistry 
Education 2 (water example - chemical triplet, language item discussion). These findings strengthen our judgements about the evidence of Antonia's PCK development related to RQ1.

The preservice teachers' specific knowledge of chemistry learners' understanding is negligible: just like Antonia, they expected better prior knowledge among the chemistry students. This was also the case regarding knowledge about the curriculum: the preservice teachers discussed how deep Antonia should go, forgetting that Antonia was following the grammar school chemistry curriculum and textbook content.

It was surprising that the preservice teachers who recognised the good aspects of Antonia's teaching, as well as the aspects that could be improved, think that they learned nothing about how to teach chemical bonding. We can only speculate that they did not understand the question correctly, and thought that their chemistry knowledge was being questioned.

\section{Limitations of the Study}

The present study has certain limitations. One of the authors was involved in the research as a teacher of Chemistry Education courses as well as a researcher, which could influence the reliability of the study. In order to ensure reliability, various instruments were used for gathering data and all of the researchers were included in the assessment of PCK evidence.

The study results are based on one participant's activities, so the findings cannot be generalised.

The PCK model (Magnusson et al., 1999) was used to categorise the PCK evidence. This is one of many PCK conceptualisations, so it is possible that some of the PCK evidence we found would be categorised in different groups according to other PCK models.

\section{Future Direction}

Although the preservice chemistry teachers were involved in various activities and the data was evaluated by three researchers, it is sometimes difficult to judge whether a certain example, procedure or other kind of treatment by the teacher can be considered as evidence of PCK. Accordingly, we plan to promote this type of research, seeking school students' thoughts about teaching and learning activities that work or do not work for them, and facing preservice teachers with school students in interviews and/or focus groups. 


\section{Conclusion}

Regarding RQ1, the component of the Chemistry Education 2 course that was redesigned in order to stimulate PCK resulted in some development of one preservice teacher's PCK related to chemical bonding. However, it was not possible to associate a positive impact with all of the redesigned areas of the Chemistry Education 2 course.

In particular, evidence of the development of Antonia's PCK of chemical bonding in the areas of the chemical triplet and the language of chemistry instruction was found regardless of which data-gathering instrument was used. According to data gathered with the lesson preparation sheet, Antonia's selfevaluation sheet and some lesson performance details, Antonia demonstrated evidence indicating a positive effect of the Chemistry Education 2 curricular changes regarding alternative conceptions related to chemical bonding.

On the other hand, she did not demonstrate development of PCK regarding intended learning outcomes related to chemical bonding, especially regarding the rules of their settings. This indicates that the changes in the Chemistry Education 2 curriculum related to Intended Learning Outcomes did not hit the target. However, after teaching, Antonia was fully aware of the scope of her success in learning objective achievement.

Taking everything into account, we conclude that the Chemistry Education 2 curriculum changes regarding the Chemical Triplet, Language of Chemistry Instruction and Alternative Conceptions have had a positive impact on the development of Antonia's PCK of chemical bonding, while the curricular change regarding Intended Learning Outcomes has not.

Regarding RQ2, Antonia demonstrated a range of evidence of her PCK of chemical bonding that cannot be attributed to participation in the component of the Chemistry Education 2 course redesigned to stimulate PCK, but is an outcome of the preceding components of the Chemical Education programme.

Based on the classification of PCK evidence into the PCK domains of Magnusson et al. (1999), Antonia showed her orientation towards science teaching by choosing a heuristic approach for the Chemical Bonding Introduction lesson, and took into account literature-based alternative conceptualisations, demonstrating an element of Knowledge of Chemistry Learners. Offering her own sequencing of teaching units, which is more sensible than that provided in the textbook, Antonia provided evidence of Knowledge about Chemistry Curricula. Conducting effective teaching related to two atoms' potential energy change simulation, chemical triplet representations and the language of chemistry instruction activities, she showed different aspects of Knowledge of 
Chemistry Instructional Strategies. By assigning students a specific language task for homework that corresponds with her awareness of concept word complexity, Antonia indicated an element of Knowledge of Chemistry Assessment.

Last but not the least, Antonia's self-evaluation data showed that her PCK about chemical bonding and, more specifically, about introductory teaching of chemical bonding, had developed during in-practice activities. This cognition highlights the importance of in-practice activities in chemistry education programmes and, consequently, its importance for the development of preservice teachers' PCK.

\section{Acknowledgements}

We would like to thank all of the preservice teachers who were involved in this research.

\section{References}

Adams, K. (2012). Beginning chemistry teachers use of the triplet relationship during their first three years in the classroom. Doctoral dissertation. Arizona State University. Retrieved from https://pdfs. semanticscholar.org/83f8/fbbao4de63e46eff7foeae18f5f6bc7994ed.pdf

Barker, V., \& Millar, R. (2000). Students' reasoning about chemical reactions: What changes occur during a context-based post-16 chemistry course? International Journal of Science Education, 22(11), 1171-1200.

Bezinović, P., Marušić, I., \& Ristić Dedić, Z. (2012). Handbook for observation and improvement of teaching. Zagreb: Education and Teacher Training Agency. Retrieved from https://www.azoo.hr/ photos/izdanja/opazanje-web-1536878204.pdf

Boo H. (1998). Students understanding of chemical bonds and the energetics of chemical reactions. Journal of Research in Science Teaching, 35(5), 569-581.

Bromme, R. (1997). Kompetenzen, funktionen und unterrichtliches handeln der lehrer [Competencies, functions and teaching of teaching]. In F. E. Weinert (Ed.), Psychologie des Unterrichts und der Schule (pp. 177-212). Göttingen: Hogrefe.

Carlson, J., Stokes, L., Helms, J., Gess-Newsome, J., \& Gardner, A. (2015). The PCK summit: A process and structure for challenging current ideas, provoking future work, and considering new directions. In A. Berry, P. Friedrichsen, \& J. Loughran (Eds.), Re-examining Pedagogical Content Knowledge in Science Education (pp. 14-27). New York, NY: Routledge.

Cochran, K. F., De Ruiter, J. A., \& King, R. A. (1993). Pedagogical content knowing: An integrative model for teacher preparation. Journal of Teacher Education, 44(4), 263-272.

Coll, R. K., \& Treagust, D. F. (2003). Investigation of secondary school, undergraduate, and graduate learners' mental models of ionic bonding. Journal of Research in Science Teaching, 40(5), 464-86. 
De Jong, O., \& van Driel, J. (2004). Exploring the development of student teachers' PCK of the multiple meanings of chemistry topics. International Journal of Science and Mathematics Education, 2(4), 477-491.

Geddis, A. N., Onslow, D., Beynon, C., \& Oesch, J. (1993). Transforming content knowledge: Learning to teach isotopes. Science Education, 77(6), 575-591.

Gess-Newsome, J. (2015). A model of teacher professional knowledge and skill including PCK: Results of the thinking from the PCK summit. In A. Berry, P. Friedrichsen, \& J. Loughran (Eds.), Re-examining Pedagogical Content Knowledge in Science Education (pp. 28-42), New York, NY: Routledge.

Joki, J., \& Aksela, M. (2018). The challenges of learning and teaching chemical bonding at different school levels using electrostatic interactions instead of the octet rule as a teaching model. Chemistry Education Research and Practice, 19(3) 932-953.

Johnstone, A. H. (1982). Macro - and microchemistry. School Science Review, 19(3), 71-73.

Magnusson S., Krajcik J., \& Borko H. (1999). Nature, sources, and development of pedagogical content knowledge for science teaching. In J. Gess-Newsome, N. G. Lederman (Eds.), Examining Pedagogical Content Knowledge. Science \& Technology Education Library, vol. 6. Dordrecht: Springer.

Markic, S., \& Childs, P. E. (2016). Language and the teaching and learning of chemistry. Chemistry Education Research and Practice, 17(3), 434-438.

Shulman, L. S. (1986). Those who understand: Knowledge growth in teaching. Educational Researcher, 15(2), 4-14.

Shulman, L. S. (1987). Knowledge and teaching: Foundations of the new reform. Harvard Educational Review, 57(1), 1-22.

Sibanda, D. (2018). What sequence do we follow in teaching concepts in chemistry? A study of high school physical science teachers' PCK. African Journal of Research in Mathematics, Science and Technology Education, 22(2), 196-208.

Taber, K. S. (2002). Chemical misconceptions - prevention, diagnosis and cure: Theoretical background (Vol. 1). London, UK: Royal Society of Chemistry.

Taber, K. S. (2003). Understanding ionisation energy: Physical, chemical and alternative conceptions. Chemistry Education Research and Practice, 4(2), 149-169.

Vladušić, R., Bucat, B. R., \& Ožić, M. (2016a). Understanding ionic bonding - a scan across the Croatian education system. Chemistry Education Research and Practice, 17(4), 685-699.

Vladušić, R. (2017). Pedagogical content knowledge about chemical bonding with particular focus on language issues in Croatia. Doctoral dissertation. Split: Faculty of Science, University of Split. Vladušić, R., \& Ožić, M. (2016). Pre-service teachers' understandings of symbolic representations used in chemistry instruction. The Turkish Online Journal of Educational Technology, 244-251. Vladušić, R., Bucat, B. R., \& Ožić, M. (2016b). Understanding of words and symbols by chemistry university students in Croatia. Chemistry Education Research and Practice, 17(3), 474-488.

Van Driel, J. H., de Jong, O., \& Verloop, N. (2002). The development of preservice chemistry teachers' 
pedagogical content knowledge. Science Education, 86(4), 572-590.

Van Driel, J. H., Verloop, N., \& de Vos, W. (1998). Developing science teachers' pedagogical content knowledge. Journal of Research in Science Teaching, 35(6), 673-695.

Yin, Robert, K. (2014). Case Study Research: Design and Methods. Thousand Oaks, CA: Sage publications.

\section{Biographical note}

Roко VLadušić, $\mathrm{PhD}$, is a senior lecturer in the field of Chemistry Education at the Faculty of Science, University of Split, Croatia. His research interests are related to pedagogical content knowledge of specific chemical concepts (such as Chemical bonding, Acids and bases, Dynamic equilibrium...), the language of chemistry instruction and chemical misconceptions issues including diagnosis and knowledge reconstruction.

Robert Bucat, PhD, is an Honorary Teaching Fellow in the School of Molecular Sciences at the University of Western Australia. His research interests are related to the challenges of learning, and therefore, of teaching, chemistry. His main interest is pedagogical content knowledge of chemistry, with particular focus on language, the importance of quality visualizations at the molecular level, and the need to distinguish between (i) macroscopic, (ii) sub-microscopic, and (iii) representational modes of operation in chemical reasoning.

MIA OžIĆ is a PhD student, enrolled in doctoral program at Faculty of Science, University of Split, Croatia. Her research interests are focused on pedagogical content knowledge related to acid-base chemistry and chemical bonding models, and to language of chemical instruction. She is engaged in development of conceptual tests for chemical misconceptions diagnoses. 